no. $28,29 / 1995$

Barbara STARIČ - STRAJNAR

Nova organiziranost

stanovanjskega področja $\mathrm{z}$

vsemi novonastalimi problemi

in ukrepi

\title{
The New Organisation of the Housing Sector together with all the New Problems and Measures
}

Stanovanja Stanovanjskogospodarstvo Privatizacija Slovenija

Končana privatizacija stanovanjskega fonda $v$ Sloveniji, ima pozitivne in negativne učinke. Srečujemo se $s$ problemi: napačne lastniške strukture, revnih lastnikov, pomankanjem zagonskih sredstev, $z$ lastninskopravnimi problemi $v$ večstanovanjskih objektih, nazadovanjem $v$ reševanju socialnih stanovanj itd. Eden od ukrepov reševanja stanovanjske gradnje je tudi politika najemnin.

Housing Housing economy Privatisation Slovenia

The accomplished privatisation of the housing stock presents both positive and negative effects. Among the problems which have emerged are; improper housing tenure structure, "poor" owners, lack of investments, legal problems related to ownership issues in multi-family housing, a reduction in social housing provision, etc. One of the measures that might contribute to increased housing construction is rent policy.
Tako kot pri vsaki tranziciji je tudi preoblikovanje družbene lastnine stanovanjskega fonda $v$ zasebno lastnino povezano z nekaterimi težavami, ki pa so, gledano dolgoročno, manjšse od prednosti, ki jih te spremembe prinašajo. Treba pa se bo navaditi, tako kot na drugih področjih, na nov sistem reševanja stanovanjskih vprašanj, prilagojen razmeram tržnega gospodarstva. Pri tem moramo izhajati iz načela, da je skrb za rešitev stanovanjskega vprašanja predvsem skrb vsakega posameznika (enabling approach), država pa s sistemom socialnih korektivov skrbi za skupine državljanov, ki brez njene pomoči ne bi mogli rešiti svojega stanovanjskega vprašanja.

Stanovanjski zakon, sprejet konec leta 1991, je določil pravno podlago za odpravo družbene lastnine na stanovanjskem področju in začel ter končal prvo od številnih privatizacij v Sloveniji. Slovenija ima skupaj dobrih 650.000 stanovanjskih enot, od tega je dobra polovica, t.j. 355.000 stanovanj, v mestnih na-seljih. Pred sprejemom stanovanjskega zakona, to pomeni pred privatizacijo stanovanjskega fonda, je bilo razmerje med številom lastnih in najemnih. (družbenih) stanovanj $67 \%: 33 \%$, po privatizaciji pa je to razmerje $88 \%: 12 \%$, spremenilo se je torej predvsem $v$ korist lastniških stanovanj.
Like in every transition, the transformation of the housing stock from public to private property has been accompanied by some problems which, in long-term perspective, are fewer than the advantages introduced by these changes. It will, however, be necessary to get used to the new system of solving housing problems which has been adapted to the circumstances of a market economy. The new approach is premised on the principle that the provision of housing is primarily the responsibility of each individual (the enabling approach). The state, through social corrective systems, caters only for the housing needs of those population groups, who are not able to solve their housing problem without state aid.

The Housing Act passed in 1991 set the legal basis for the elimination of public property in the housing field and, thus, started and accomplished one of a series of privatisation processes in Slovenia. Altogether there are just over 650,000 housing units in Slovenia, more than half of which, i.e. 355,000 units, are in urban settlements. Before the Housing Act was adopted, that is, before privatisation of the housing stock, the ratio between owner-occupied and rented (public) housing was 67 $\%: 33 \%$. After privatisation, this ratio changed to $88 \%: 12 \%$, in favour of owner-occupation. 
Zakon ločuje med lastnim stanovanjem (to je stanovanje, ki ga stalno uporabljajo lastnik ali njegovi ožji družinski člani) in med štirimi kategorijami najemnih stanovanj: profitno, službeno, neprofitno in socialno stanovanje. Skrb za profitna in službena stanovanja je prepuščena posameznikom in podjetjem (delodajalcem), za gradnjo socialnih stanovanj so pristojne lokalne skupnosti (občine), neprofithe stanovanjske organizacije pa za gradnjo neprofitnih stanovanj

\section{Problemi, ki so nastali po privatizaciji}

Po privatizaciji stanovanjskega fonda se je pokazalo, da je bila cena stanovanj prenizka, saj je bilo več kot $60 \%$ vseh stanovanj odkupljenih v enkratnem znesku, čeprav je zakon omogočal $10 \%$ polog in dvajsetletno odplačilno dobo. Zaradi ugodne cene se je za odkup odločil tudi tisti sloj prebivalstva, ki obveznosti v zvezi z lastništvom (vzdrževanje stanovanja, tekoče in investicijsko vzdrževanje stanovanjske hiše, davki ipd.) težko izpolnjuje. Tako se sedaj v Sloveniji srečujemo s problemom "revnih lastnikov": Rešitev tega problema vidimo $v$ nadaljevanju procesa prestrukturiranja, v lasiniških menjavah med samimi lastniki stanovanj, in sicer glede na odločitve lastnikov o: spremenjeni lokaciji stanovanja, stanovanjih z nižjimi obratovalnimi in vzdrževalnimi stroški kar zadeva opremljenost stanovanja, morebitnih preselitvah $v$ manjše stanovanje. Vse te možnosti bi lastnikom zagotovile določena denarna sredstva, s katerimi bi se deloma rešili bremena, ki je povezano zlastnino stanovanja. Vse skupaj pa bi precej vplivalo na trg stanovanj in na normalizacijo ponudbe in povpraševanja, posredno pa tudi na znižanje cene stanovanj. Ne glede na vsa kasnejša spoznanja in razprave o ceni privatizacije, pa je dejstvo, da je stanovanjska privatizacija aktivirala znatne prihranke prebivalstva, ki so bili večinoma $v$ tuji valuti. Važno pa je tudi dejstvo, da se je to zgodilo ravno v času monetarnega osamosvajanja države.
The Housing Act distinguishes between owner-occupation (housing that the owner or his/her immediate family members permanently use) and four rented housing categories: private rented, employer (pool), non-profit and social housing. The provision of private rented and pool housing is the responsibility of individuals and companies (employers), while the constuuction of social housing is the responsibility of local authorities (municipalities). Non-profit housing organisations are charged with the construction of non-profit housing.

\section{Post-Privatisation Problems}

After the privatisation of the housing stock, it was discovered that house selling prices had been very low, as more than $60 \%$ of all public housing was paid for in cash although the law allowed for a $10 \%$ deposit and a twenty-years repayment period. Due to the favourable price, even that part of the population which can hardly meet the demands and obligations of ownership (maintenance, operating and rehabilitation costs, taxes, etc.) was able to purchase housing. We are thus faced with the problem of "poor owners". The solution to this problem lies in the continuation of the restructuring process which will involve housing exchanges between owners. These exchanges will depend on decisions taken with respect to: changes in housing location, house equipment which affects operation and maintenance costs and likely moves into smaller housing units. These possibilities will provicle the owners with financial resources with which they could alleviate some the burdens arising from house ownership. All this will, in turn, markedly influence the housing market and the normalisation of supply and demand, indirectly leading to a reduction in house prices.

Irrespective of all later revelations and discussions regarding the cost of privatisation, the fact still remains that housing privatisation activated people's substantial savings which, at the time were de- 
Naslednji problem je povezan z lastninskopravnimi razmerji v večstanovanjskih hišah in z upravljanjem teh hiš v takih okoliščinah. Skupni prostori, deli, objekti in naprave $v$ večstanovanjskih hišah ter funkcionalno zemljišče so namreč solastnina vseh etažnih lastnikov, pri čemer je solastniški delež vsakega etažnega lastnika sorazmeren vrednosti njegovega stanovanja glede na skupno vrednost etažne lastrinine $v$ celi hiši. Za odločitve v zvezi z odtujitvijo, spremembo namembnosti, ustanovitvijo hipoteke, stvarnih služnosti, prenovo, izboljšavami in podobno je potrebno soglasje vseh solastnikov. Glede na to, da gre pri večstanovanjskih hišah večinoma za hiše, ki imajo deset ali več lastnikov, pa tudi za hiše s sto in več lastniki, to ni enostavno. S spremembo zakona, ki je že v parlamentarnem postopku, vsaj za spremembo namembnosti, prenovo in izboljšave ne bo več potrebno soglasje vseh solastnikov, marveč bo zadoščal sporazum solastnikov, ki s svojimi solastniškimi deleži sestavljajo skupaj več kot polovico vrednosti stanovanjske hiše. Predpogoj za dobro upravljanje in nemoteno obratovanje hiše pa je skrbna izbira dobrega, usposobljenega upravni$k a$ in finančna disciplina lastnikov.

Leta 1991 je začela veljati nova finančna zakonodaja, s katero so bila razveljavljena določila o stanovanjskem prispevku iz dohodka in združevanje sredstev iz čistega dohodka. $\vee$ dveletnem obdobju privatizacije, ko je pritekal denar od kupnin za prodana stanovanja, odprava teh prispevkov niti ni bila tako opazna, še posebej, ker je bil na podlagi stanovanjskega zakona ustanovljen Stanovanjski sklad Republike Slo-venije, kamor se je steklo in se še steka (zaradi obročnega odplačevanja kupnine) del kupnin, pridobljenih s privatizacijo bivših družbenih stanovanj. Po končani privatizaciji pa je zaradi pomanjkanja denarja stanovanjska gradnja občutno nazadovala. Stanovanjski sklad Republike Slovenije pod določenimi pogoji sicer kreditira gradnjo neprofitnih stanovanj in prvi nakup lastnega primernega stanovanja, vendar je obenem pri socialni gradnii, ki je v izključni pristojnosti občin, vidno posited, mostly, in foreign currency. It is also important to recognise that this happened at the time when Slovenia was establishing monetary independence.

The next problem is related to the legal aspects of house ownership in multi-family housing and to the management of these houses under these circumstances. The common areas, parts of the building, objects and installations in multi-family houses, together with the functional grounds around them, are all common property of all the apartment owners. The individual share of each owner, on common property is proportional to the value of his housing unit in relation to the total value of all housing units in the multi-family house. All decisions related to alienation, change of function, establishment of a mortgage, material servitude, renewal, improvements and the like, require the consent of all owners. Considering that in the majority of the multifamily houses, there are ten or more owners (some houses have a hundred or more owners), this consent is not so easy to achieve. The proposed amendment to the law, which is presently in parliamentary procedure, will abolish the requirement to secure unanimous consent in case of: effecting functional changes, renewal and improvement. An agreement, reached between owners whose property together constitutes more than half the total value of the multi-family house, will be sufficient to effect the changes.

A precondition for the good management and smooth operation of the multi-family house is the careful selection of a good, qualified manager, and the financial discipline of the owners.

In 1991 a new finance law came into effect which abolished the provisions on housing contributions from income and the collection of funds from net income. During the twoyears privatisation period, when there was an inflow of house sell money, the abolition of these contributions was not felt much. This was especially so because the Housing Act also introduced the Housing 
največje nazadovanje. S ponovnim zagotavljanjem dodatnih proračunskih sredster za dokapitalizacijo Stanovanjskega sklada Republike Slovenije ter $z$ vse večjim zanimanjem za ustanavljanje neprofithih stanovanjskih organizacij za gradnjo tiste kategorije najemnih stanovanj, ki so v Sloveniji najbolj potrebna, pa lahko pričakujemo na ponovno oživljanje stanovanjske gradnje.

Stanovanjsko gradnjo mora spodbujati tudi politika najemnin, ki so bile v preteklem obdobju daleč prenizke, da bi lahko krile dejanske stroške, ki nastanejo pri uporabi stanovanja. Posledica tega je bilo pospešeno propadanje stanovanjskega fonda, saj so bila stanovanja oziroma stanovanjske hiše neustrezno vzdrževane. Dvig kvalitete vzdrževanja stanovanjskega fonda in spodbuditev interesa za gradnjo neprofitnih in socialnih stanovanj sta bila glavna razloga, da so se neprofithe najemnine štiri leta po uveljavitvi nove stanovanjske zakonodaje dvignile na raven, ki zagotavlja kritje stroškov, ki nastajajo v zvezi z gradnjo, tekočim in investicijskim vzdrževanjem hiše, upravljanjem in amortizacijo.

Barbara Starič - Strajnar, dipl. iur., Ministrstvo za okolje in prostor - Stanovanjski sektor
Fund of the Republic of Slovenia which collected, (and still collects instalment payments) some of the sell money from the privatisation of former public housing. Due to lack of funds after privatisation, housing construction has considerably declined. While the Housing Fund of the Republic of Slovenia, under specific conditions, offers loans for the construction of non-profit housing, and for the first time purchase of an appropriate housing unit, the construction of social housing, which is the exclusive responsibility of local authorities, has evidently declined most. The continued provision of additional budget funds in order to increase the capital of the Housing Fund, together with the ever increasing interest in the creation of non-profit housing organisations, for the construction of that category of rented housing which is on high demand in Slovenia, may indicate a revival of housing construction.

Rent policy must also encourage housing construction. In the past, rents have been far too low to cover the real costs which arise from the use of housing. The result has been the rapid deterioration of the housing stock, since the apartments and housing blocks were inadequately maintained. A rise in the quality of maintaining the housing stock and the provision of incentives for the construction of non-profit and social housing were the main reasons why non-profit rents have, four years after the implementation of the new housing act, ultimately risen to the level which ensures cost recovery, in relation to construction, operation, maintenance, management and rehabilitation costs.

Barbara Starič - Strajnar, B. L., Ministry of the Environment - Housing Department. 